\title{
Cretan Protolinear Script: The Sixth-Vowel Set of Syllabograms
}

\author{
Ioannis K. Kenanidis ${ }^{1} \&$ Evangelos C. Papakitsos ${ }^{2}$ \\ ${ }^{1}$ Primary Education Directorate of Kavala, Kavala, Greece \\ ${ }^{2}$ School of Pedagogical and Technological Education, Iraklio Attikis, Greece \\ Correspondence: Ioannis K. Kenanidis, Primary Education Directorate of Kavala, Ethnikis Antistaseos 20, 65110 \\ Kavala, Greece. E-mail: ioakenanid@sch.gr
}

Received: February 27, 2018; Accepted: March 13, 2018; Published: March 30, 2018

\begin{abstract}
This paper presents a set of eighteen signs of the Minoan scripts, used for syllables of the Consonant-Vowel (CV) type. What these eighteen syllabograms have in common is their vowel, which is a kind of "schwa", treated here as the "sixth vowel" of the Minoan scripts, counted after the usual five vowels: "a", "e", "i", "o" and "u". Most of these syllabograms are considered to be of unknown phonetic value, while a few are known to be used for the Mycenaean Greek " $\alpha \imath$ " ([əj]]). The presented approach is conducted according to the theory of the Protolinear script, being the script that all the Minoan scripts evolved from, including Linear A, Linear B and Cretan Hieroglyphics. A detailed study on the nature of that "schwa" and its evolution from - and to - related vowels precedes the presentation of the syllabograms. In conclusion, it is demonstrated that the phonetic value of each syllabogram corresponds to the Sumerian name (in a conservative dialect) of the object depicted by the syllabogram, thus more light is shed on the linguistic ancestry of the Minoan scripts, the practice followed for their creation and the phonetic values of eighteen hitherto un-transliterated syllabograms.
\end{abstract}

Keywords: Aegean scripts, Cretan Protolinear, Minoan Civilization, Sumerian language, syllabograms

\section{Introduction}

It has been forty years since Willetts (1977, p. 100) firstly proposed the existence of a Cretan Protolinear script, followed indirectly by Owens (1996) and Schoep (1999, p. 266) later on, who suggested or suspected the common ancestry of Cretan Hieroglyphs and Linear A. In 1992, Kenanidis (1992) initially demonstrated the Linear B (and other Minoan scripts') syllabograms' phonetic values as equivalent to the Sumerian names of the objects depicted by those syllabograms. Syllabograms are signs used to write the syllables of words. In all Minoan scripts, each syllabogram usually renders a syllable of the Consonant-Vowel (CV) form, with only very few exceptions of signs rendering $\mathrm{C} / \mathrm{j} / \mathrm{V}, \mathrm{C} / \mathrm{w} / \mathrm{V}$ or $\mathrm{CVCV}$ forms (Kenanidis \& Papakitsos, 2017). In mainstream archaeology, the origins of the Aegean scripts are still considered mysterious (Haarmann, 2008, pp. 42-43), as before (Dickinson, 1994, p. 143), although the paleographic similarity of the Aegean scripts to the Sumerian pictography has been also partially demonstrated by Davis (2011, pp. 65-68). An almost complete reconstruction of Cretan Protolinear (henceforth CP) was released a few years ago (Kenanidis, 2011-2013) and selectively presented recently (Kenanidis \& Papakitsos, 2015b; Papakitsos \& Kenanidis, 2015). The term CP is conceived as the script that all the Bronze Age Aegean scripts evolved from, including Linear A (henceforth LA), Linear B (henceforth LB) and Cretan Hieroglyphics (henceforth $\mathrm{CH}$ ) that is the ornamental version of CP (Papakitsos \& Kenanidis, 2016).

Intriguingly, at least $1 / 10$ of the syllabograms of LB, which conveys the Achaean (Mycenaean) Greek language, have been considered un-transliterable until recently (Melena, 2000, p. 2); also of LA (Haarmann, 2008, p. 13; Owens, 1990), a script conveying other languages of Bronze Age Crete, including a local Semitic (probably Akkadian) dialect (Kenanidis, 2011-2013, p. 82; Woudhuizen, 2005). The conveyed language of CH is still considered unknown, as well, although it has been demonstrated that the relation of the $\mathrm{CH}$ script to $\mathrm{CP}$ and to the Archaic Sumerian language provides meaningful and coherent translations in many instances (Papakitsos \& Kenanidis, 2016; Kenanidis, 2016). On the other hand, through the CP theory, almost all of the unknown syllabograms acquire an "identity", that is an explicit phonetic value depending on a known pictographic origin. So, resulting also to the clarification of hitherto misinterpreted or un-interpreted signs, the syllabogram set of the sixth vowel will be presented in this work, according to the CP concept (Kenanidis, 2011-2013, p. 41-59). 


\section{Method}

A well-known feature of Sumerian phonotactics should be noted now too, that the coda consonant of Sumerian words was silenced, unless the word was followed by a vowel, e.g., of a suffix or other component (Kenanidis \& Papakitsos, 2015b, p. 336). This is indicated by enclosing the Sumerian words' final consonants in parentheses. The main reference for Sumerian vocabulary used is The Pennsylvania Sumerian Dictionary of the University of Pennsylvania, abbreviated as "PSD" (Note 1).

A few decades ago it was a generally accepted theory what Kramer (1963, p. 306) wrote: "Sumerian has six vowels: three open vowels $a, e, o$ and three corresponding close vowels $\tilde{a}, \hat{e}, u$ ". Since then, research has not made any true advancement into Sumerian vocalism, rather only confusion has grown on the matter. Sumerology today is an almost abandoned study, if we judge by the scarcity of serious Sumerologists in recent years and the fact that the PSD has never been updated since 2006, June 26. In fact, the vocalism of all natural languages can be seen to originate in a 3-vowel system, typically "a, $\mathrm{i}$, $\mathrm{u}$ ", which (by a distinction between closer versus opener forms) is extended to a system of up to 6 vowels, schematized as in the following arrangement (Table 1):

Table 1. The typical 6-vowels system.

\begin{tabular}{llll}
\hline & front (unrounded) & central(unrounded) & back (rounded) \\
\hline (relatively) close & $\mathrm{i}$ & $\partial$ & $\mathrm{u}$ \\
(relatively) open & $\mathrm{e}$ & $\mathrm{a}$ & $\mathrm{o}$ \\
\hline
\end{tabular}

The reason when we use quotation marks (e.g., "a") instead of IPA (e.g., /ä/) is that we do not point to an exact description of sound within the frame of the modern International Phonetic Alphabet (IPA), but rather to approximations, within the frame of individual languages' simple vocalism systems. For example, what we describe as "e" could be realized as IPA/E/ or some similar sound, and what we describe as "a" could be IPA /e/ or anything similar to IPA /ä/. The vowel letters as presented in Table 1 refer to the describing terms in the table itself, and those terms are relative and not absolute: "open" in the table means "more open than the corresponding close vowel", and "central" means "less front than the corresponding front vowel, and less back than the corresponding back vowel". So the simplified representation of Table 1 can refer to different languages, mostly ancient ones (of which there is no audio recording available), and it avoids diacritic marks which can be really confusing for the non-specialist. This simplified representation also disregards the distinction of vowels by length or tone (pitch), as such distinctions are not relevant to the subject of this work.

It is only some recent languages that display a more complicated vocalism than that of Table 1 . Rounding of front vowels appears only in recent languages (e.g., German but not Proto-Germanic; common in French but only marginally in Latin). As to the rounded front vowels in Turkic and neighboring languages, we find that these vowels were not original but at some time appeared in women's speech, as it is attested in Sumerian Emesal (the feminine sociolect), which, indeed, often rounded the front vowels.

There are many old and new natural languages with 3-vowels ("a, i, u”) as Protosemitic, classical Arabic, and old Caucasian languages; also many with a 5-vowels system ("a, e, i, o, u”) as Spanish, modern Greek, Proto-Dravidian and Japanese; and many with a 6 vowels system, resembling that in Table 1, as Malay-Indonesian, Russian and Bulgarian: such languages have a really central vowel in place of the "ə" of Table 1, as Malay-Indonesian and Russian, but other languages have something slightly different, as Bulgarian $/ \gamma /$ (unrounded close-mid back vowel): although a back vowel, Bulgarian $/ \gamma /$ is more related to $/ \mathrm{a} /$ than to other back vowels, because back vowels are typically rounded, while the unrounded are typically non-back ones. It is not accidental that artificial languages intended to be as easy as possible for all nations (for example, Esperanto, Ido, Toki Pona and many others less widely known) usually have a five vowel system, as that in Table 1 without "ə". The Turkish language, as also Turkic languages in general, displays a polarized system of only back and front, no central vowels: the typical Turkish 8-vowel system is perfectly symmetrical, as both the front and the back vowel ranges consist of 4 vowels, equally divided between close and open, rounded and unrounded.

If we investigate deeper into the past, we find that even the distinction of closer versus opener vowels was not present in the most ancient reconstructable languages (and therefore in the original Proto-Human language, for those who hold the opinion of monogenesis, i.e., one common origin of all languages). Proto-Indo-European had "e" and "o", and it is still much debated whether it also had an "a" (that is /ä/ and/or /o/; recently, /a/ has been also suggested); Indo-European "i" and "u" came only from the semivowels /j/ and /w/ respectively. Proto-Semitic had 
only "a", "i", " $u$ " (short and long), and even these did not differentiate roots; just as the Indo-European true vowels ("e", "o" and the debated "a") did not differentiate roots too.

It may be considered a novelty, although largely outside the scope of this work, if we suggest that the original vowels distinction was a matter of articulatory position:

- front of the mouth, lips (hence back vowels);

- middle of the mouth, hard palate (hence front vowels);

- back of the mouth, velum (hence central vowels).

Many languages did not develop a closer central vowel (“ə”), because the central position of the tongue was essentially for expressing the "velum position", which is more clearly audible with an open rather than closer mouth (and not with an extremely back position of tongue, because the extreme back position of tongue meant not the back end of the mouth cavity but the throat that was associated with the rounded vowels, as it is still nowadays: "In most languages, roundedness is a reinforcing feature of mid to high back vowels rather than a distinctive feature. Usually, the higher a back vowel, the more intense is the rounding" (Note 2).

Since Kenanidis (1992) concluded that Sumerian is a distant relative of r-Turkic languages (of the Bolgar branch) today represented by Chuvash (Kenanidis \& Papakitsos, 2013), and that Mesopotamian Sumerian had an 8-vowel system analogous to that of Turkish, this led him to think that the Sumerian "close a" was identical or similar to the Turkish /u/ (written as dotless " 1 " in the Latin alphabet, and as " $ы$ " in the Turkic languages that use the Cyrillic alphabet). Therefore, Kenanidis wrote " 1 " (dotless "i") for the Sumerian "close a" since his 2011-2013 work. However, writing " 1 " for the Sumerian close "a" can be misleading and it can hardly be accurate for all the 3 suggested dialects of Sumerian (Cretan, Cypriot and Mesopotamian dialects). Kenanidis considers the Cypriot dialect more similar to the Mesopotamian one (Kenanidis, 2011-2013, p. 179-191), because (apart from geographical proximity) both these present the rounded front vowels $(/ \varnothing /$ and $/ y /)$ in place of which the Cretan dialect shows the corresponding unrounded forms (Note 3).

To sum up the reasoning about Sumerian "close a" being a back vowel (/w/ or rather $/ \gamma /)$ :

- Since Sumerian developed a symmetrical 8-vowel system, it is reasonable to assume that it was a polarized (back-front) system like that of Turkic languages, all of which have the vowel /w/, while Chuvash, the only surviving r-Turkic language, uses $/ \gamma /$ (also a back vowel) much more than $/ \mathrm{u} /$. The Slavic Bulgarian language has substituted the Bolgar (r-Turkic) language, so the Slavic Bulgarian $/ \gamma /$ could be due to a Turkic-Bolgar influence.

- The Cuneiform script represents the "close a" usually as "a", which is natural if it was a back vowel, although the same Cuneiform "a" could also apply to a central vowel.

- Sometimes after non-occlusive consonants, the "close a" is represented as "u" in Cuneiform, which is the most common way that people represent unrounded back vowels when they do not have them in their native language.

However, and importantly, even if Mesopotamian Sumerian "close a" was a back vowel, there is strong evidence that the Cypriot Sumerian "close a" was central and not back: the evidence is that the syllabograms used for Sumerian "close a" came to be used for Cypriot Greek "e" or "i". Namely:

- Cypriot Greek syllabogram TE from CyproMinoan "də" (see subsection 3.3 below).

- Cypriot Greek syllabogram Paphian LE from CyproMinoan "lə" (see subsection 3.9).

- Cypriot Greek syllabogram I from CyproMinoan “ə” (see subsection 3.1).

- Cypriot Greek syllabogram RI from CyproMinoan "rə" (see subsection 3.14).

- Cypriot Greek syllabogram KE from CyproMinoan "cə" and probably also from "ce" (in a few instances, like this one and the next, it must be two different CyproMinoan syllabic signs that contributed to only one sign of the Greek Cypriot syllabary, because they came to be similar in shape and in pronunciation; see subsection 3.8).

- Cypriot Greek syllabogram MI from CyproMinoan "mə" and probably also from "mi", as these two became similar in shape in the Cypriot Greek syllabary (see subsection 3.10).

This evidence is decisively strong, because the Cypriot Greek syllabary in both Paphian and non-Paphian types used only 22 signs for all syllables with I and E, and a big part: 6 of those syllabograms, demonstrably came from CyproMinoan syllabograms with "ə". This means that "ə" sounded similar to "E" and "I" to the ears of the Semitic 
people who used the original (Sumerian) CyproMinoan script, and then transmitted it to the Greeks. We cannot suppose that " $ə$ " had already turned to " $\mathrm{i}$ " in the Cypriot Sumerian dialect, because:

- Some of the "ə" signs came to be used for "i", but more of them for "e", in the Cypriot Greek syllabary.

- We know the original CyproMinoan sign for "le", which became the non-Paphian Greek LE, also we know the original CyproMinoan sign for "li", hence Cypriot Greek sign LI; but the Paphian Greek LE, which was used even in the first extant Cypriot Greek syllabic inscription $\left(11^{\text {th }}\right.$ century BCE; see Figure 9), was a different sign, because it came not from LE or LI; it was from the original CyproMinoan LO, but came to be used for Greek LE.

Therefore, we can be sure that the Cypriot Sumerian "close a", was really a central vowel. So then the question arises whether the Cretan Sumerian "close a" was also a central vowel, as (at least the main dialect of) Cretan Sumerian had only 6 vowels; but the matter is not so simple. We must bear in mind that in all Turkic and related languages (like Manchu) there was a clear understanding that all the back vowels are "yang", and therefore "manly", while all front vowels are "yin", and therefore "feminine". A summary of this concept has been recorded about Manchu (Note 4):

"The vowel harmony found in the Manchu language was traditionally described in terms of the philosophy of the I-Ching. Syllables with front vowels were described as being as "yin" syllables whereas syllables with back vowels were called "yang" syllables. The reasoning behind this was that the language had a kind of sound symbolism where front vowels represented feminine objects or ideas and back vowels represented masculine objects or ideas. As a result, there were a number of word pairs in the language in which changing the vowels also changed the gender of the word. For example, the difference between the words "hehe" (woman) and "haha" (man) or "eme" (mother) and "ama" (father) was essentially a contrast between the front vowel, [e], of the feminine and the back vowel, [a], of the masculine counterpart".

Exactly the same concept existed, and still exists, in the Turkic languages. As an example, one of the authors' grandfather, liked to sing a song in Turkish, (Note 5) but instead of "saçlarıma" he always sang "saçlarime", which is wrong according to the Turkish vowel harmony requiring back vowels in all the syllables; but he sang the last syllables with front vowels. Why? He explained that he made the vowels front, so as to make the song sound more genteel. In Turkish, back vowels are called "kalın", meaning "thick, fat", while front vowels are called "ince" ("thin, slender"), and it is not only the Turks who realize that back ("fat") vowels give a feeling of strong, robust, coarse, rough, manly things, while the front ("thin") vowels give a feeling of thin, refined, elegant, feminine things. We have also found that the ancient Turkic word "elik" (roe deer) was originally *alık (with back vowels and velar "k"), but it was already in the $9^{\text {th }}$ century A.D. changed into "elik" (front vowels and palatal "k"), so as to express the slenderness, light movements, and fine beauty of the roe deer. Many other communicational devices in the Turkic and related languages were considered "masculine" or "feminine". For example, the hiragana script in Japan was considered feminine. For many centuries, Japanese men would write only in kanji and katakana but not in hiragana, which was reserved for women. Today however, the morality is no longer so strict, so both sexes can use all types of Japanese characters: kanji, hiragana and katakana.

Something analogous happened with the back and front vowels in the dialects of Sumerian. In Mesopotamia, women used a dialect, known as "Emesal" (the name means "feminine language"), different from the mainstream Sumerian. Emesal phonology could labialize front vowels, turn palatal consonants to dentals, $/ \mathrm{y} /$ to $/ \mathrm{m} /$, and turn some vowels to front ones (without labialization). A man could not use Emesal, unless he was openly an effeminate man, as male sacred prostitutes and some priests of the great Goddess; those priests were called "gala". That word has survived in Greek " $\gamma \alpha \dot{\lambda} \lambda \lambda \circ \varsigma$ " ("gallos"), as the effeminate priests of Cybele were called in Hellenistic times (Note 6). But, for any other man it would be a disgrace to use Emesal, and this meant that men deliberately avoided the Emesal phonological tendencies, even to the extent of hypercorrection, which made them turn some labial stop consonants into velars, because labialization was a common Emesal tendency for $/ \mathrm{y} /$ and front vowels. For this reason, we believe that the "close a" was back (that is, "manly") in Mesopotamia and Crete; while in Cyprus, Emesal was obviously not used, as it merged with the mainstream language - analogous to hiragana, katakana and kanji used both by men and women in Japan today. However, there is an indication that Emesal did exist in Crete and the places that were colonized by Sumerian Cretans, including Sicily and southern Italy: the Latin word "securus" originates from the Cretan Sumerian *segyl /sekyl/, which shows /i/ to /y/, an Emesal trait. The word appears as "sikil" (= segil, meaning "secure, safe, intact, unharmed, pure, virgin") even in Mesopotamian Sumerian which not sparingly used /y/ and generally front rounded vowels in the mainstream dialect, after Emesal influence. The word's cognates appear in Turkish as "sağ" and "sağlam" (with back, "manly" vowels), which indicates that probably even in original Sumerian and in the Cretan mainstream dialect it was *sagəl; but it turned to segil in 
Mesopotamia, and even to *secyl in Cretan Sumerian women's dialect. This means that a feminine sub-dialect could exist also in the Cretan dialect of Sumerian, although it was never used in public and the available syllabary had no signs to represent the special characteristics of that feminine sub-dialect.

The conclusion is that the Sumerian "close a" was originally a central vowel, which remained central in Cyprus, whereas it turned to a back vowel in Mesopotamia and Crete (main/men's dialect), while Emesal often turned that "close" central vowel to front (and then many of such words with front-from-central vowel were adopted by the mainstream Mesopotamian Sumerian language, because Emesal influence was really strong). This explains a wellknown phonological tendency of Mesopotamian Sumerian: turning the close "a" and open "a" into "i" and "e" respectively (Kenanidis \& Papakitsos, 2013, p. 34: rule 5.0.3). We shall refer to this rule many times below while examining the syllabograms with the vowel "ə". We must also clarify that the "close a" in Mesopotamia and Crete was a mid-close $/ \gamma /$ and not exactly close / $/ \mathrm{w} /$ as in Turkish, because if it were / $\mathrm{w} /$ it would be almost always rendered as " $\mathrm{u}$ " by the Akkadian scribes, but this is rarely the case; also the connection to Mycenaean Greek "schwa" points to the Sumerian "close a" being mid-close $/ \gamma /$ and not very close /u/. Another indication may be Chuvash using very often "ă" $(/ / /)$ but only rarely/u/, while Chuvash is the only r-Turkic language today, and it has been demonstrated (Kenanidis \& Papakitsos, 2013) that Sumerian can be classified with the r-Turkic, but not with the z-Turkic languages.

With the knowledge of the phonological features and tendencies described above, constituting the core methodological tool for examining the data presented herein, the Minoan and the Mycenaean Greek "schwa" will be evidenced by the syllabograms used for it, in the following section. The reader will again be reminded of the writing conventions, especially for the letter "ə".

\section{Results}

The sixth-vowel set of eighteen syllabograms are presented below; the images in the figures are retrieved from: the digital archives of the French School of Athens; the Cuneiform Digital Library Initiative (CDLI), where all images of pre-Cuneiform signs used, when not from ATU (Falkenstein, 1936) or otherwise stated, came from (namely the webpage in Note 7); the images for LB and Linear Cypriot Greek signs came from Ventris \& Chadwick (1953), except where otherwise stated. The image of the oldest Linear Cypriot Greek inscription (figure 9d) is from Palaeoloexicon (Note 8).

\subsection{Syllabogram “ə”}

The "sixth vowel of Linear B" (here written "ə") was a really mid central vowel, probably inherited in Achaean ("Mycenaean") Greek from the Proto-Indo-European language (figure 1). However, the syllabograms with the Achaean Greek [ə] occurred only where the [ə] was followed by /j/, as [əj] (what later became the diphthong "ai" in Classical Greek).

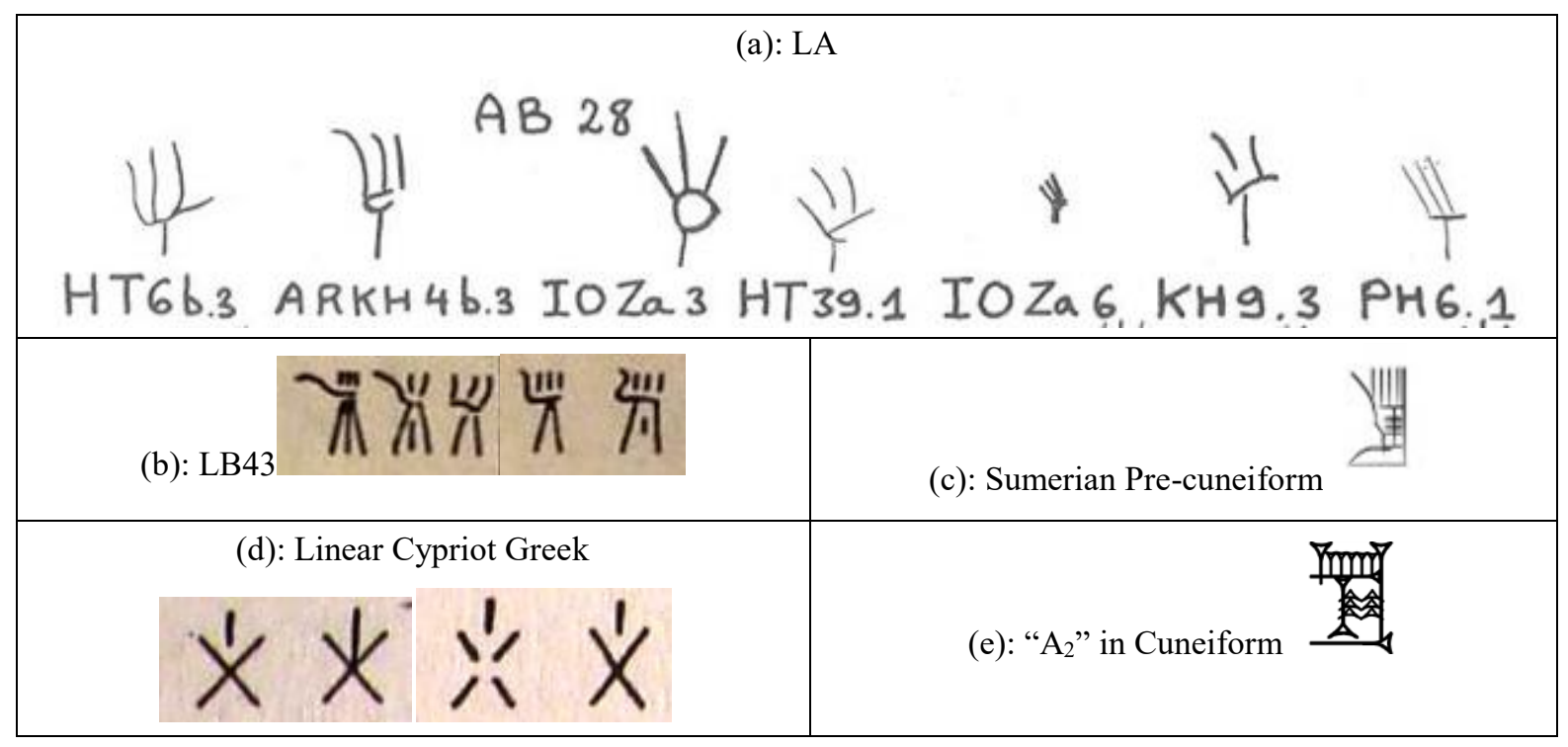

Figure 1. The signs of forearm 
So, the Achaean Greek "ə" (normally a central vowel) was near but not identical to the Sumerian "ə" (usually a back vowel) although the Sumerian syllabograms with "ə" were used for the Greek [əj]. That Greek ə(j) standing alone as a syllable, was represented by the syllabogram LB43 (Kenanidis \& Papakitsos, 2015b, p. 341) homomorph to AB28 of LA (figure1a), differing from the "hand" sign by showing a longer arm and usually less than five fingers, since it was intended to depict a forearm instead of a palm. The LB43 sign is hitherto named "a”"; it was the same as the CP sign for the Sumerian syllable "ə" that was represented as a sketch of a (fore)arm, because the (fore)arm, a symbol of power, was named " $\partial$ " in Sumerian (found in Cuneiform as "a 2 "). Again we must clarify that LB normally does not represent " $\mathrm{j}$ " and many other "weak" consonants like the nasals, "r", "l", "s" unless followed by vowels. The Cuneiform script is notorious for lacking both accuracy and consistency in representing the sound of languages. So we have an extra reason for using quotation marks (" ") when transcribing words from Cuneiform. Following the common system of transliterating from the Cuneiform, italics are used for non-Sumerian words (mostly Akkadian), and ordinary upright letters for Sumerian words, while CAPITAL letters are used for the names of signs (which are often different to the signs' readings; every sign can have different, often many readings, decided only by the context, in a way similar to the Japanese kanji). Determinatives (i.e., un-pronounced classifying signs) are superscripted.

\subsection{Syllabogram "bə"}

One of the most common logograms in LB is the sketch of wheat (figure 2b), also common in LA (figure 2a) and $\mathrm{CH}$ (figure 2c). In $\mathrm{CP}$ the sketch of wheat was used also as a syllabogram (as well as the sketches of the other two important cereals of Sumerians: barley and emmer). In Mesopotamian Cuneiform, wheat is found as "gig" in all 599 cases that the word is cited (PSD). This "gig" was derived from an older "bə(g)", because of certain phonetic rules (Kenanidis \& Papakitsos, 2013, p. 34: rule 5.0.3, p. 35: rule 5.0.14). So, as a syllabogram, the sketch of wheat conveyed the syllable "bə" (/pr/ in CP).

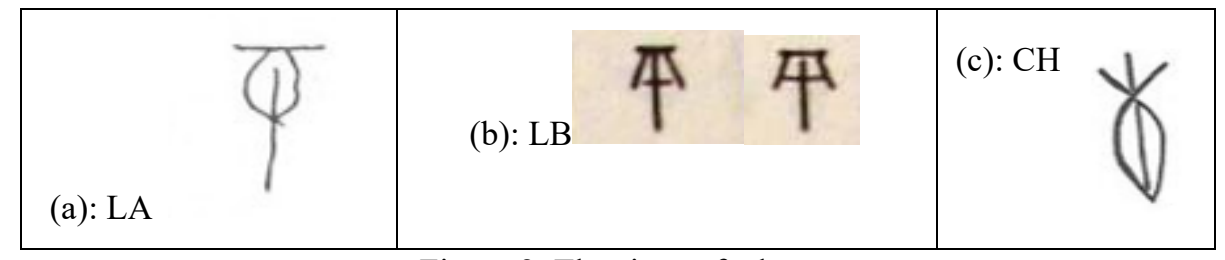

Figure 2. The signs of wheat

\subsection{Syllabogram "do"}

The syllabogram LB18 (figure 3a) is very rare and consequently reported as of unknown use. Its variants are analogous to the usual sign of Sumerian pre-Cuneiform and later Cuneiform for "fire" (figure $3 \mathrm{~b}$ ). So we understand that LB18 depicted a torch, to mean "fire". The common Sumerian word for fire was: "izi", "wr. izi; izi $_{2}$ "fire; brazier", Akk. išătu". The word "izi" was formerly "ədə", (stressed on -də), in the light of particular phonetic rules (Kenanidis \& Papakitsos, 2013, p. 34: rule 5.0.3, p. 37: rule 5.0.31). Consequently, it was the Achaean syllable " $\delta \alpha \iota "$ (dəj) conveyed by the syllabogram LB18 (CP "də").

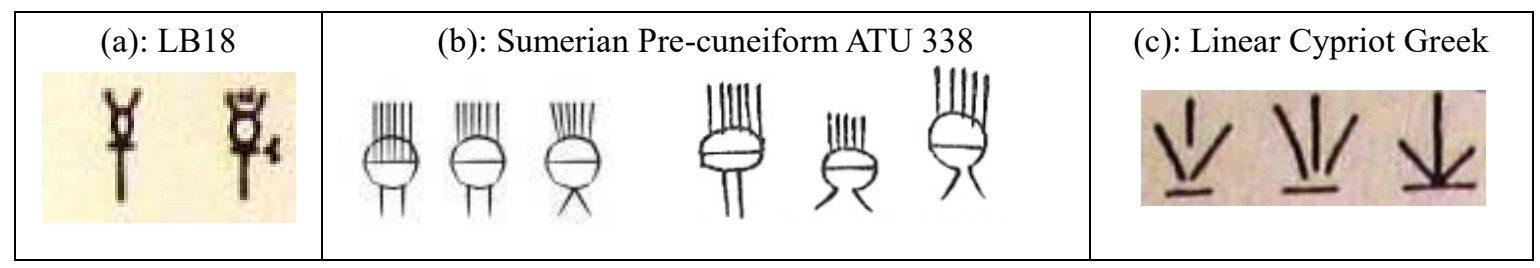

Figure 3. The signs of torch/fire

\subsection{Syllabogram " $\theta$ ə"}

The Sumerian word "gazi" denoted a spice that was considered indispensable for meat, judging from relevant proverbs. The PSD gives:

- $\quad$ wr. gazi; gazi 2 , "mustard seed or licorice”, Akk. kasû.

It is not known today what spice exactly the "gazi" was. It is only by guessing translated as "mustard seed or 
licorice". Both in "gazi" and many other words that meant spices we find the syllable "zi". Actually, in the following words the syllable "zi" was written with the Cuneiform sign "ZI" itself:

- "zibatum", wr. zi-ba-tum; zi-ib-ba-tum ${ }^{\text {sar }}$, "an aromatic seed; a garden plant", Akk. zibnatu; zibìtu;

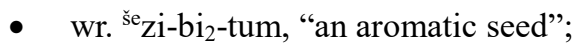

- wr. zi-bi, "cumin";

- wr. zi-zi-bi 2 -a-num 2 , "an agricultural product";

- e-zi-zu sar , "a vegetable", Akk. ezizzu ("an alliaceous vegetable");

- " u 2 li-li-bi-zi-da, "a thorny plant", Akk. dadaru ("a foetid plant, perhaps centaury").

In the word "zazaga" (= "a spice"), although not written with the sign "ZI", we find a reduplication of "zag", which is derived most probably from / $\theta ə p /$ (Kenanidis \& Papakitsos, 2013, p. 34: rule 5.0.1, p. 35: rule 5.0.15, p. 37: rule 5.0.32) meaning "spice". In pre-Cuneiform, the pictogram "ZI" is written with a spice image added to (right, left or below) the symbol that meant "herbaceous plants", to avoid confusion with the pictogram "GI" that meant "reed" and resembled "herbaceous plants" (figure 4a). "ZI" was named after the same word found (either alone or in derivatives and composites) in Cuneiform as "zi(b)" or "zibi", meaning "spices" in general, the most common and favorite Sumerian spice being the cumin. Thus, the Sumerian word for spices in general but especially cumin was originally " $\theta \partial(\mathrm{p})$ ". Of $\mathrm{CP}$, the syllabogram " $\theta \partial$ " is attested as a sign with many similar variants in LA, rarely as A316 (figure 4b) and usually as A303 (figure 4c), which is apparently used as a logogram (that is, a sketch of something with economic value) but not as a syllabogram, as such a syllable was absent in the Semitic language recorded. On tablets recording the delivery of sheep intended for consumption (as salary), we see that spices were given together, which were denoted by this logogram. Being a very common sketch of such an important commodity, this sketch of cumin, " $\theta \partial(p)$ " in Sumerian, must be the CP sign that was used for the syllable " $\theta$ ". The syllabograms had to represent culturally significant things. It would be too hard to find any other culturally significant thing named " $\theta$ ”" and represented by such an easily drawn, readily recognized and frequently seen sketch.

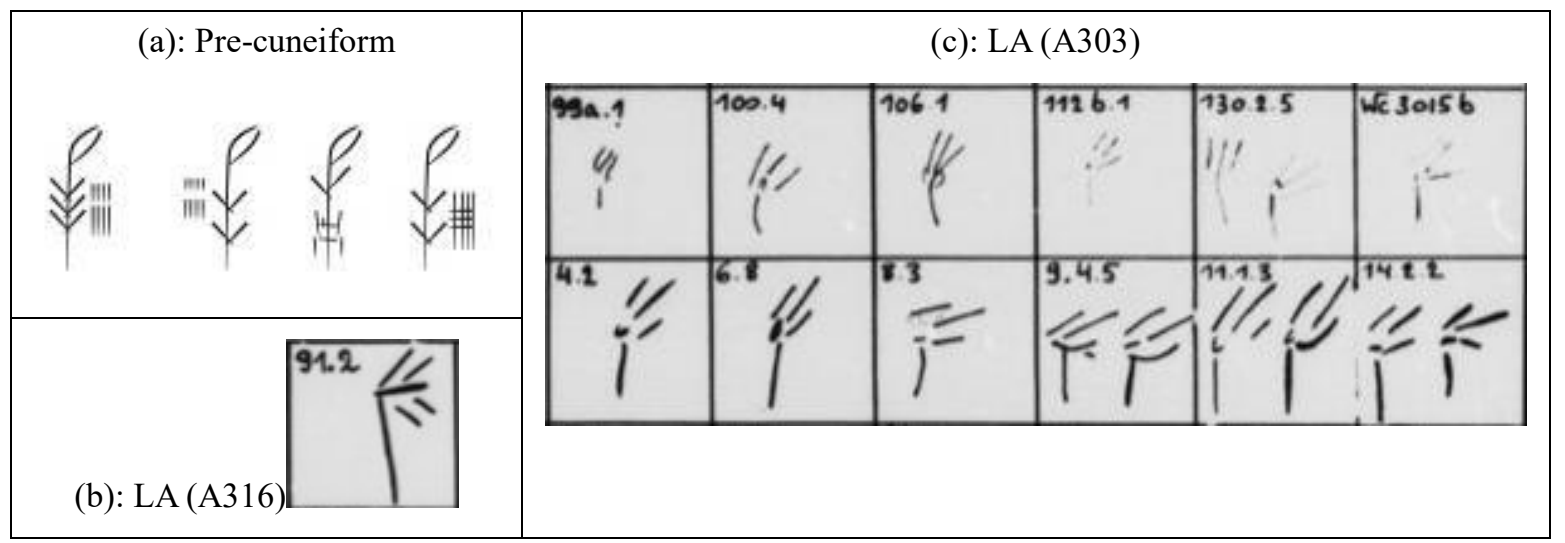

Figure 4. The signs of cumin

\subsection{Syllabogram "yə"}

For speakers of Greek and of many other languages, the syllable " $\mathrm{g} ə$ ” ("yə”) sounds extremely unfamiliar. It was certainly not used in Achaean Greek (LB), and generally not in languages conveyed by LA. So, it may be attested only in CH (figure 5a,b), where rarely some signs seem to depict "eggs". The word for "egg(s)" is found in the Cuneiform as "nunuz" (basically "egg", metaphorically "ovoid beads", and in AHW (Soden, 1958-1981) "nunuz" is also glossed with Akkadian $l \bar{l} p u(m)$ "descendant"). This "nunuz" has been formed by reduplication (apart from compounds and suffixed forms, all Sumerian nouns were monosyllabic); the sign NUNUZ (figure 5c) was also read as "nuz", "nus", and "nunu". So, the original Sumerian word for eggs must have been "yə $(\theta)$ "; the coda consonant is not clear, but Cuneiform " $z$ " stands for Sumerian $/ \theta /$. That word for eggs was probably cognate to Sumerian "nu" (the word is attested in Cuneiform as "wr. nu = Akk. lipištu"; the pronunciation of "nu" glossed only once on available tablets, as "nu.ú", a typical way of rendering " $y ə$ " in a language that had no " $y$ " or "ə"). The Akkadian translation "lipištu", in PSD glossed "male genitalia; sperm; offspring" and in AHW "scrotum" or "sperm", obviously meant "testicles". Such a sign was not taboo in writing, as the signs that depict male (figure 
17) and female (figure 16) genitals are explicit in the Minoan scripts and both in Cuneiform and pre-Cuneiform as well. As in Cuneiform, the pre-Cuneiform sign for eggs (NUNUZ) depicts always a pair of eggs (figure $5 \mathrm{~d}$ ), and even the Akkadian translations "nunuz =lippu $(m)$ " and "nu=lipištu" are related to each other, thus we can understand that "eggs" and "testicles" were related to each other in Sumerian culture and language, so it is even really possible that some scribes would choose "eggs", while others would choose "testicles" to depict in order to convey the syllable "yə". So we estimate that the syllabogram for "yə" was a sketch of two eggs, (or, possibly, testicles), named "yə( $\theta$ ?)" in Sumerian.

(a): Possible form in $\mathrm{CH}$

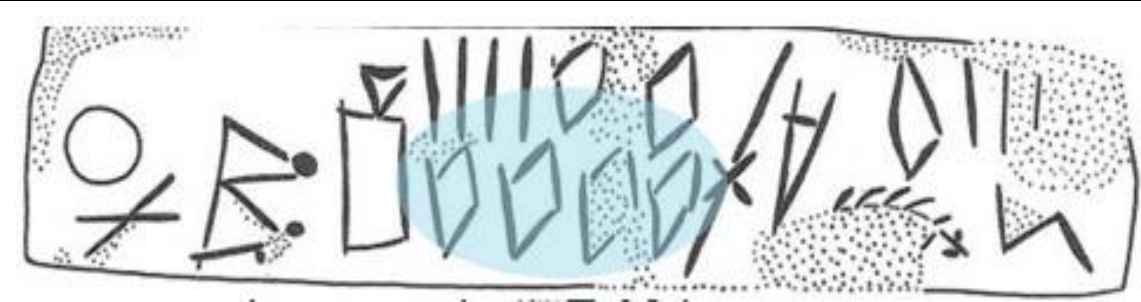

(b): Another possible form in $\mathrm{CH}$

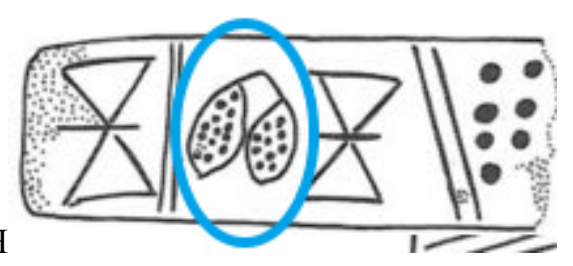

(c): Cuneiform sign NUNUZ

(d): Pre-Cuneiform forms of NUNUZ
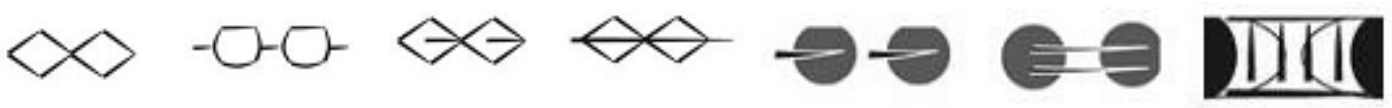

Figure 5. The signs of eggs/testicles

\subsection{Syllabogram "hə"}

The syllable /ha/ is not found in LB, where the whole set of h-syllabograms was not used, except rarely for "hu" and "ha" (Papakitsos \& Kenanidis, 2015, p. 735). What we transcribe as " $h$ " for convenience, was in fact $/ x /$ in Sumerian, not very proper to use for Greek $/ \mathrm{h} /$. Yet in LA (figure 6a) and in $\mathrm{CH}$ (figure 6b: one of the signs highlighted in blue) there was a syllabogram that depicted a fruit.

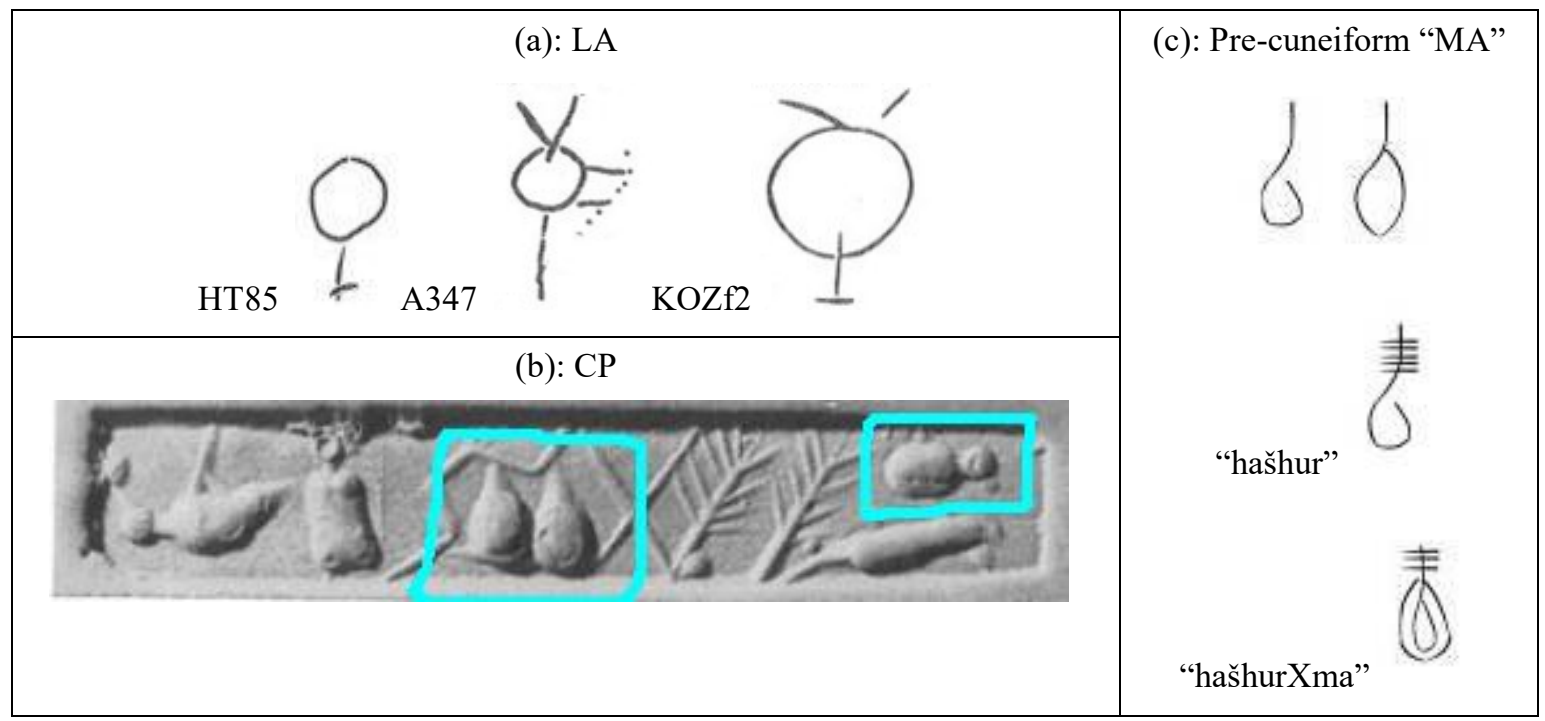

Figure 6. The signs for fruit 
In pre-Cuneiform there was a pictogram (which ended up as the Cuneiform sign called MA), depicting a fruit, used for the words "hašhur" or "hašhurXma" (figure 6c). Various forms of the sign show a fruit and its stem, its stone and small leaves near its stem. The PSD gives:

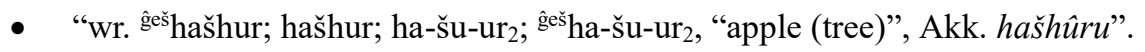

(There is indeed doubt as to what kind of fruit the hašhûru was. There is no evidence for "apple"; we have arguments in favor of apricot, which are omitted here, otherwise this work would be too lengthy).

As there were no Sumerian root words bigger than monosyllabic, "hašhur" etc. is analyzed into "haš" and "(h)ur". The second component was an original "hor" (meaning "sweet juicy fruit"), that could not be rendered in the Cuneiform unless as "(h)ur". So, as most convenient to the scribes, the word "hə(r)" was used to name the easily drawn CP sign for the syllable "hə".

\subsection{Syllabogram "ja”}

The syllable /ja/ was not used in LB, because such a syllable was really strange to the Greek language. The syllabogram AB188 though, quite often found in LA (figure 7a), is certainly similar to the well-known Sumerian pre-Cuneiform pictogram named "URU", meaning "a city" (figure 7b), while "city" and "state" was one and the same concept for Sumerians, as for ancient Greeks too. The most common form of "URU" is the first on the left (figure 7b), but there are many known variants (figure 7b: ATU 621-629). The sketch delineates a set of tall buildings, reminiscent of a modern skyline. This Mesopotamian sign is interpreted in PSD as:

- $\quad$ iri (eri, uru); iriki ; uru$_{2}$; uru uri $_{11}$; iri $_{11}\left(\right.$ eri $\left._{11}\right)$, "city”, Akk. àlu,

where the pronunciation of the sign URU ("city") is rendered in all these ways: iri; eri; ulu $_{4}$; $\mathrm{er}_{4}$; $\mathrm{ir}_{4}$; uru; ere: all these were efforts to approximate the original Sumerian pronunciation *jor(ə), where the final "ə" had to be added for enabling the coda " $r$ " to be pronounced (the well-known rule of Sumerian phonology, e.g., see Kenanidis \& Papakitsos, 2013, p. 37: rule 5.0.33). As the sign for "city (-state)" was surely used for a syllable in LA, so also in $\mathrm{CP}$, and the depicted thing was one of the commonest words in the speech of Sumerians, this was the CP syllabogram for "jə", named after "jə(r)" (=city).

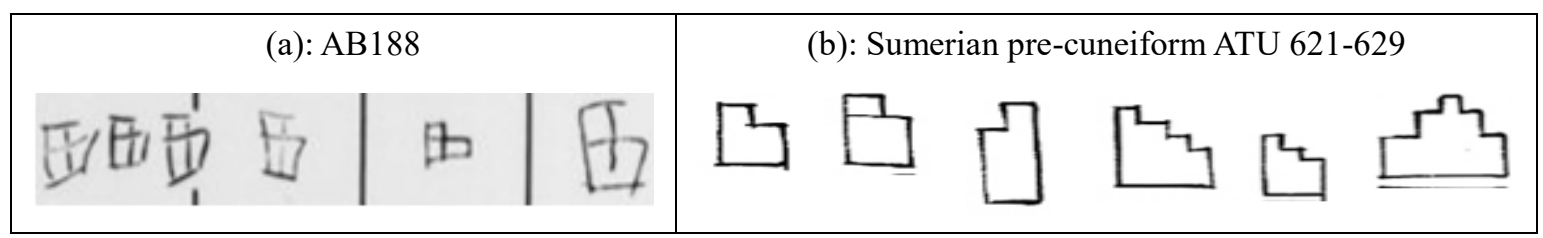

Figure 7. The signs for city-state

\subsection{Syllabogram "cə"}

The syllabic sign for "cə" is not found in LB, as it was not useful for the Greek language. Yet, this syllabogram is quite common in LA (figure 8a), and it has been also found in the latest extant Eteocretan inscription (Kenanidis \& Papakitsos, 2015a; figure 8b). The very same form is one of the commonest signs in Sumerian Cuneiform and pre-Cuneiform (figure 8c), where the number of upper vertical lines (above the horizontal one) varies in ATU, from 3 to 8 . Of course $\mathrm{CP}$ used the simplest possible form, according to the script's matured tendencies.

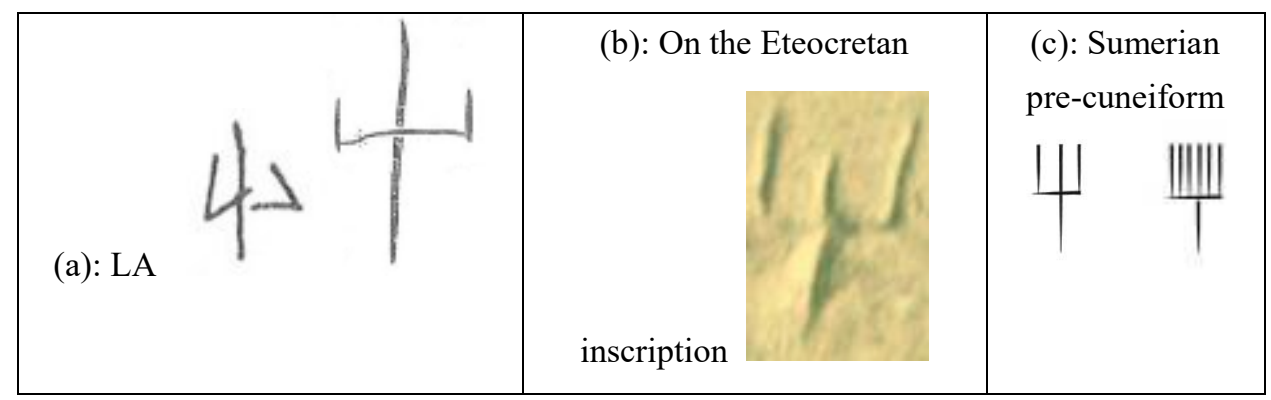

Figure 8. The signs for "greatness" 
This Mesopotamian pictogram is named GAL (where " $\partial$ " is transliterated "A" as usually), one of the commonest words in Cuneiform; there is a related word "gula" in Cuneiform, and we have observed that "gal" was conceptually large (i.e., "great; grand") while "gula" meant physically "big". As Cuneiform "gal" ("great, grand") corresponds to "cə(l)" in the Cretan dialect of Sumerian, this was the CP syllabogram for "cə".

We take this opportunity to explain that, in our transcription system for old languages, "c" stands for a "tense" palatal, corresponding to the "lax" palatal that we represent as "k"; of velars (or relatively back consonants), we represent the "tense" as "g" and the "lax" as "q". We had to use such a simplified system instead of the IPA because the exact nature of the old language sounds can be eluding, while the more important thing in our study is not the exact and accurate description of the ancient phonemes, but the relation among themselves, e.g., a relation between relatively back and relatively front consonants, not necessarily exactly velars versus accurately palatals.

3.9 Syllabogram "lə"

The syllable "lə" is not found in LB, as generally " $ə$ " was a rare and secondary sound in Greek, while the syllable " $\lambda \alpha \iota$ " (ləj) was sometimes conveyed by the CP sign for "rə" (figure 14). The CP syllabogram for "lə" (figure 9a) is found in the latest extant Eteocretan inscription (Kenanidis \& Papakitsos, 2015a; figure 9b) and it was used in the Cypriot Greek (Paphian type) syllabary for the syllable "LE" (figure 9c), including the oldest Cypriot Greek inscription where the "LE" sign can be seen circled in blue, its internal tiny lines not very clear in the photograph (figure 9d). This syllabogram is found in some $\mathrm{CH}$ documents as well (figure 9d). It depicted a type of pointed spade. The Sumerian tool in figure 9e was a shovel, properly called MAR, although, later on, Cuneiform expectedly lost the distinction between these similar tools: the "olə" was always pointed; the AHW (Soden, 19581981), under the entry "allu" informs us that it was the symbol of the Egyptian king. The SPD gives the name of that tool as: "wr. al; gešal; urudal, "hoe; pickax; hoeing", Akk. allu", and also gives the readings "ala”" and "il $1_{10}$ " for the sign AL. In accordance to the common phonological rule about consonant codas in Sumerian (Kenanidis \& Papakitsos, 2013, p. 37: rule 5.0.33), it is understood that the word was "olə", originally stressed on -lə; so, as the most convenient to the scribes, the pointed spade ("ələ”) sign was used in both Cretan and Cypriot Protolinear script for the syllable "la".

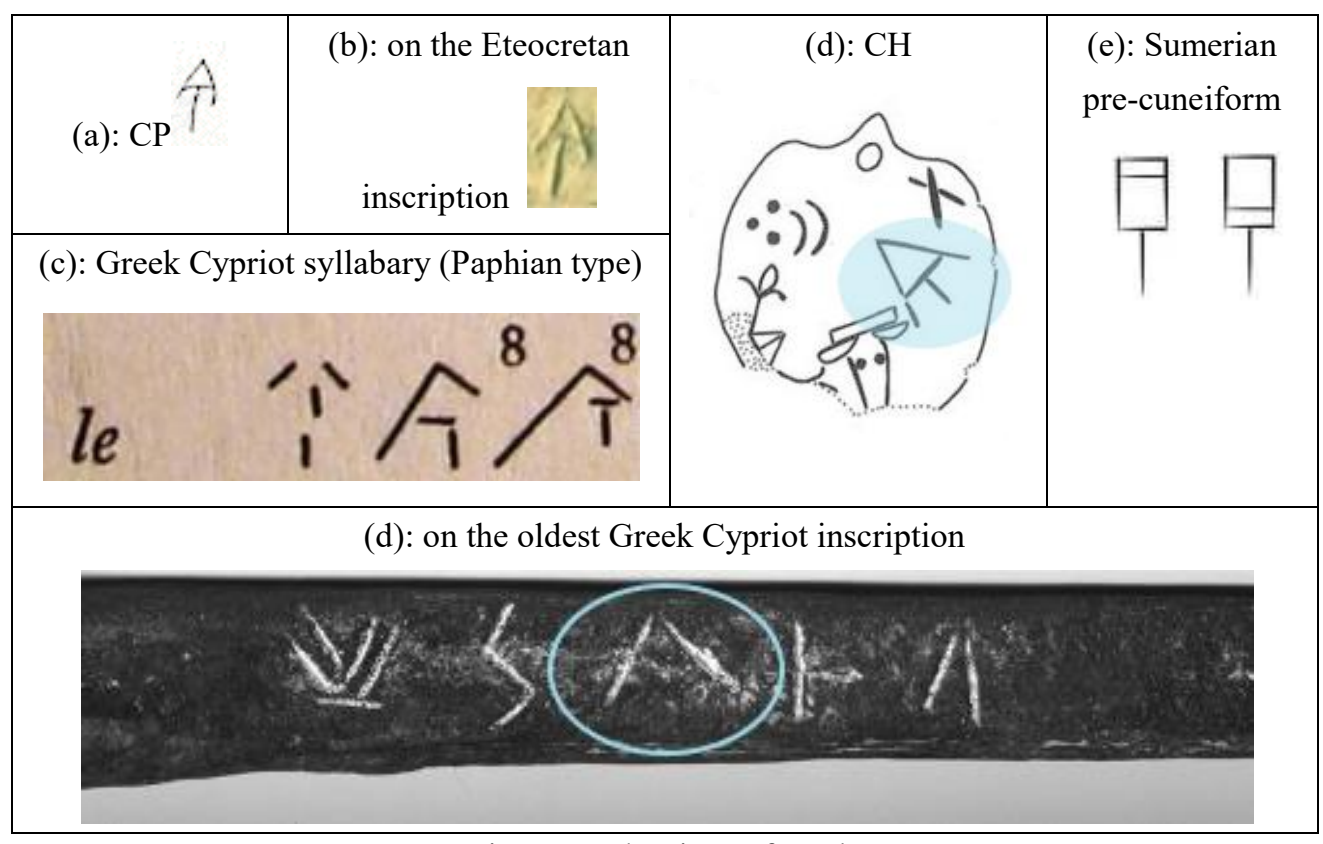

Figure 9. The signs of spade

\subsection{Syllabogram "mə"}

The syllabogram LB86 (figure 10b) is considered of unknown phonetic value in LB, but it is generally agreed that it depicts a ship. In LA, this syllabogram often looks shoddy, as other signs too on LA tablets (figure 10a). In Sumerian pre-Cuneiform, the pictogram has the forms ATU 216-219 (figure 10c), useful to give us an idea of what ships and boats looked like in Mesopotamia (mostly in the rivers). Any kind of ship/boat in Sumerian Cuneiform was "ma2". Hence the word "malah", in PSD: 
- wr. $\mathrm{ma}_{2}-\mathrm{lah}_{5} ; \mathrm{ma}_{2}-\mathrm{lah}_{4} ; \mathrm{ma}_{2}-\mathrm{lah}_{6} ;{ }^{\mathrm{lu}}{ }_{2} \mathrm{ma}_{2}-\mathrm{lah}_{5} ;{ }_{2} \mathrm{lma}_{2}-\mathrm{lah}_{4} ; \mathrm{lu}_{2} \mathrm{ma}_{2}-\mathrm{lah}_{6}$, "sailor", Akk. malahhu (from "ma," $=$ "ship" + "lah" = "driving").

This word for "sailor" has survived as a loanword not only in Akkadian but also in other languages of the Eastern

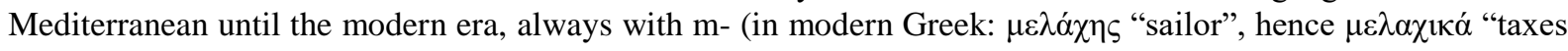
paid by Christian sailors in the Ottoman Empire"). Since the consonant of the syllable was $/ \mathrm{m} /$, the vowel was definitely " $\rho$ ", because all other syllabograms of the CP $\mathrm{m}$-set are well known. Thus, the syllabogram "mə" depicted a ship, called "mə".

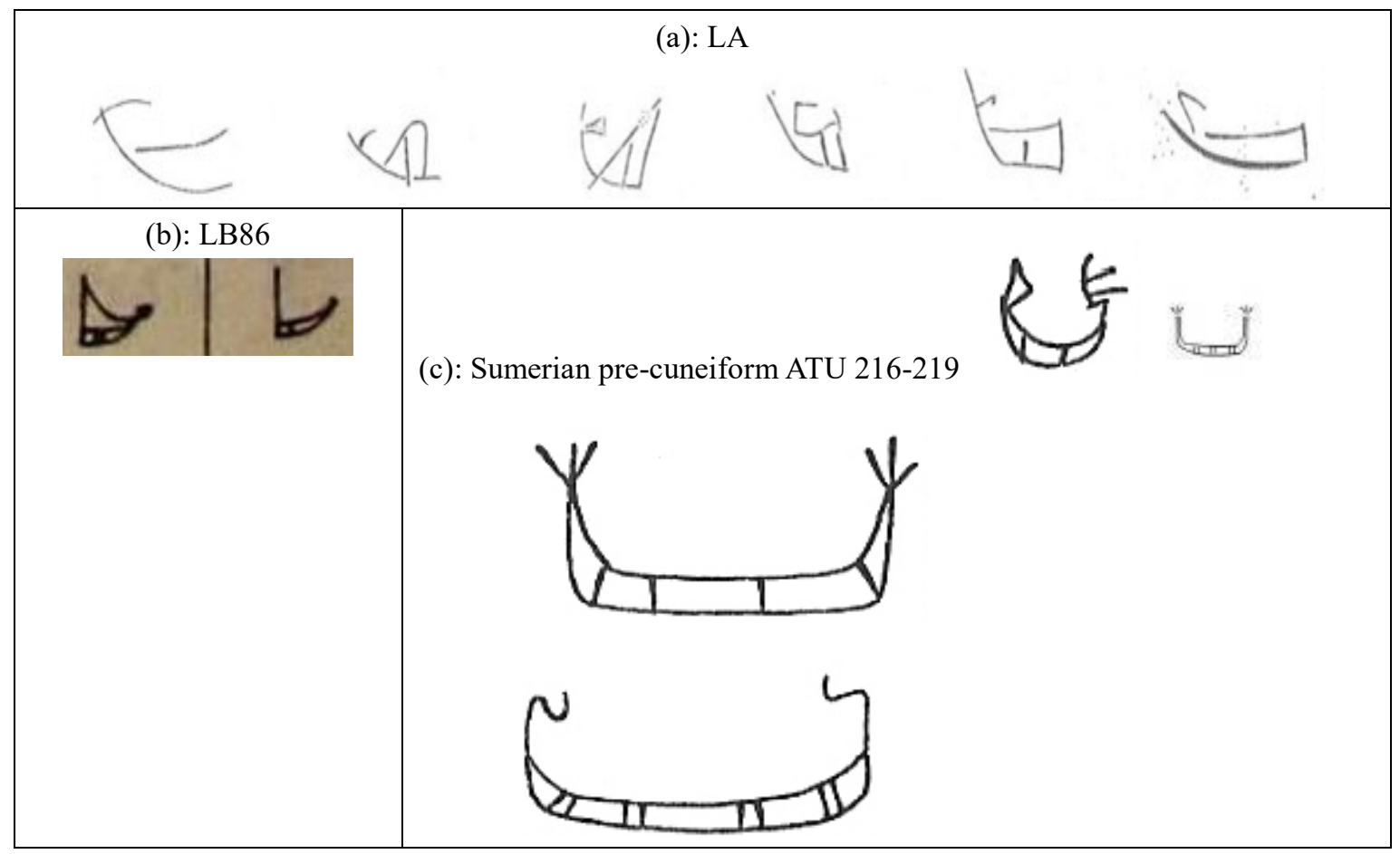

Figure 10. The signs of ship

\subsection{Syllabogram "nə"}

We know only one (but perfectly clear) occurrence of the syllabogram LB89 (figure 11b), in a word painted on a clay vessel, reading "wa-*89-a", which has never been possible to be interpreted as a Greek word. The sign LB89 too is considered of unknown phonetic value. The same sign is found on the LA tablet HT96 (figure 11a). This sign is homomorph to the Sumerian Cuneiform $\mathrm{NA}_{2}$ (figure 11c), of which many pre-Cuneiform shapes are known (figure 11d and e); the forms of figure 11e come from Driver (1976, p. 55), where it is explained that the sign depicts a Sumerian bed (of various forms). The sign read "na." was used both as a verb ("to lie down") and a noun ("bed"). For "bed", the dictionary entries also include "nud" and "nu2", both written also with Cuneiform $\mathrm{NA}_{2}$. Another reading given for $\mathrm{NA}_{2}$ is "nad 3 ", indicating that the word was actually "nə(t)", where the Akkadian lexicographers approximated the Sumerian " $ə$ " sometimes with "a" and sometimes with "u" (Kenanidis \& Papakitsos, 2013, p. 34: rule 5.0.5). The LB word "wa-*89-a" is very interesting since we know that "bedroom" in Sumerian Cuneiform is "a $\mathrm{a}_{2}$-nud-da" or " $\mathrm{e}_{2}-\mathrm{nu}_{2}$ ", where " $\mathrm{a}_{2}$ " and " $\mathrm{e}_{2}$ " are the same word and sign, exactly corresponding to the syllabogram "wa" of LB (Kenanidis \& Papakitsos, 2015b, pp. 341-342), which here meant "room". So the word "wa-nə-a" found on the Achaean vessel is exactly the same word found in Cuneiform as "a $2_{2}$ nud-da" or "e $e_{2}-\mathrm{nu}_{2}$ ". Probably, the writer of "wa-nə-a" meant "wa-nət-a", not written with "-ta" because it was considered self-evident that the sign was to be read "not" with its coda consonant, since it meant what it depicted: a bed ("nət"), while a vowel followed (i.e., "-a"); otherwise it would be odd to have the sign "a" at the end of a word: the sign "a" normally occurs only in the beginning of words. The final -a must have been the locative case suffix, so "wa-nə-a" ("wanəta") meant "in the bedroom". Written on the vessel, it meant that the vessel was to be kept in the bedroom. The form of the syllabogram LB89 (figure 11b) is between its two Sumerian pre-Cuneiform forms (figure 11e), depicting a typical Sumerian bed in front view, with its headboard, footboard, and sheets tied to the bottom of its legs. This gave the phonetic value to the CP syllabogram for "nə". 


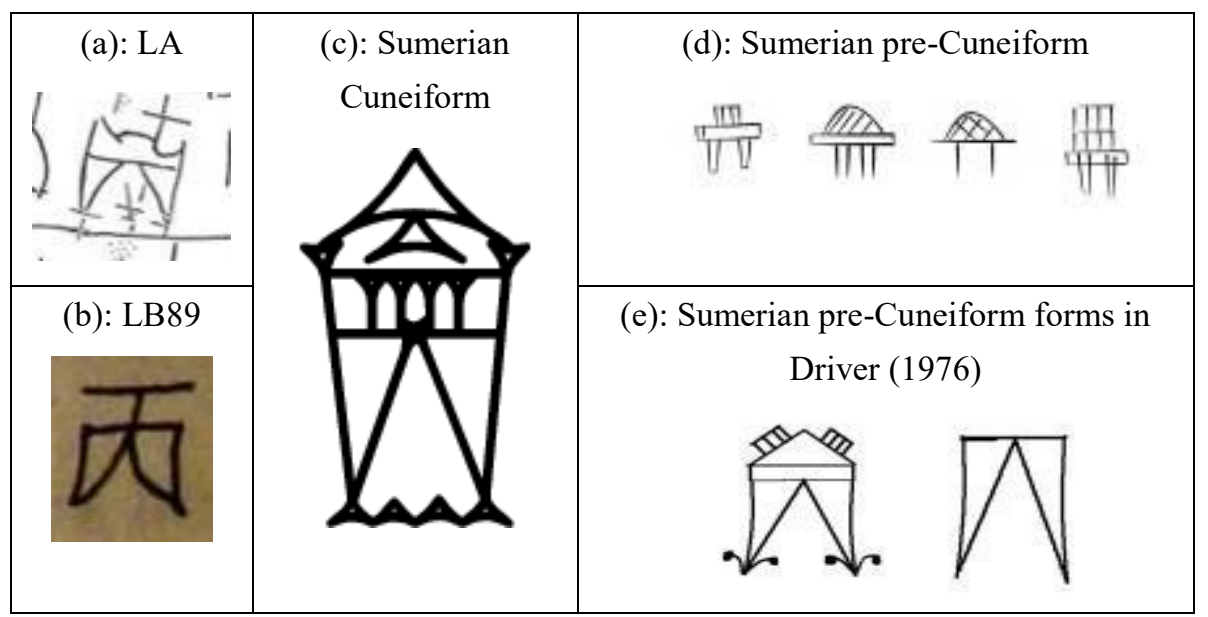

Figure 11. The signs of bed

\subsection{Syllabogram "pə"}

The rare, declaredly of unknown phonetic value, syllabogram LB82 (figure 12b) is even rarer in LA (figure 12a). It is clearly homomorph to the Sumerian pre-Cuneiform signs ATU 850-853 (figure 12c), which depicted irrigation ditches that start from a canal. The canals were of paramount economic importance to the Sumerians of Mesopotamia. In PSD, we find:

- "par" [CANAL]: wr. pa; pa $_{6}$, “(small) canal, irrigation ditch", Akk. atappu; palgu; pattu.

This "par", "pa5", "pa6", actually "pə(r)", is exactly what the syllabogram LB82 depicted to convey the syllable "pə" (of course, it could not be "pa", as the LB sign for "pa" is different, very common and well known).

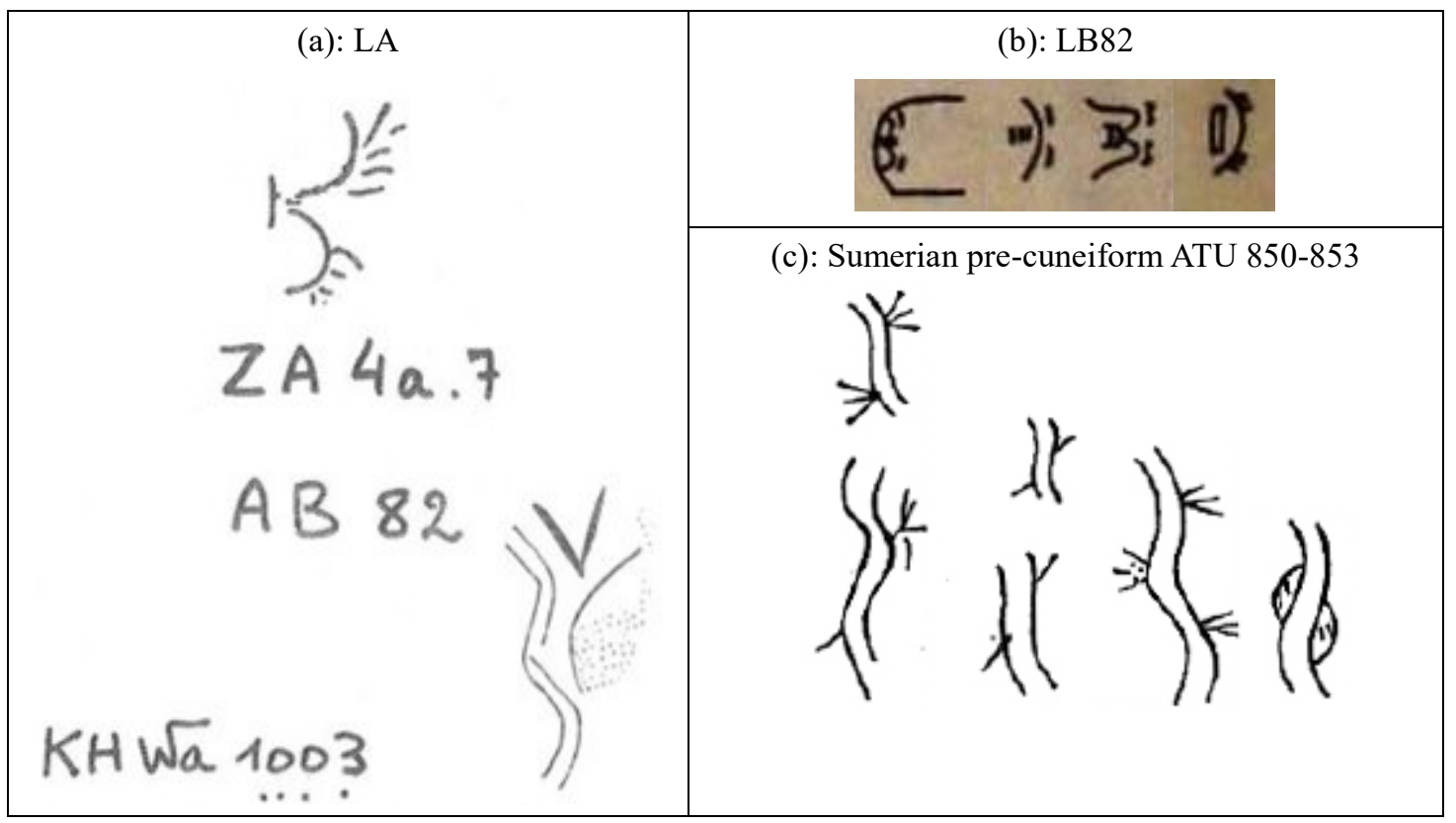

Figure 12. The signs of canal

\subsection{Syllabogram "qə"}

The syllabogram "qə" of CP is found only in LA (figure 13a), since it was not useful for the Greek language (LB). Its mirror image (figure 13b) is analogous to the Sumerian pre-Cuneiform pictogram ATU 61 (figure 13c) that depicted a fox. The equivalent Cuneiform sign (figure 13d), is used for "ka5" or "ka5-a" (= "ka10"), meaning "fox". The word for fox was "qə" in the Cretan Sumerian dialect (the usage of "q" is explained under syllabogram "cə"; 
see also Kenanidis \& Papakitsos, 2013, p. 34: rule 5.0.8). This was the CP sign for the syllable "qə", being a sketch of a fox.

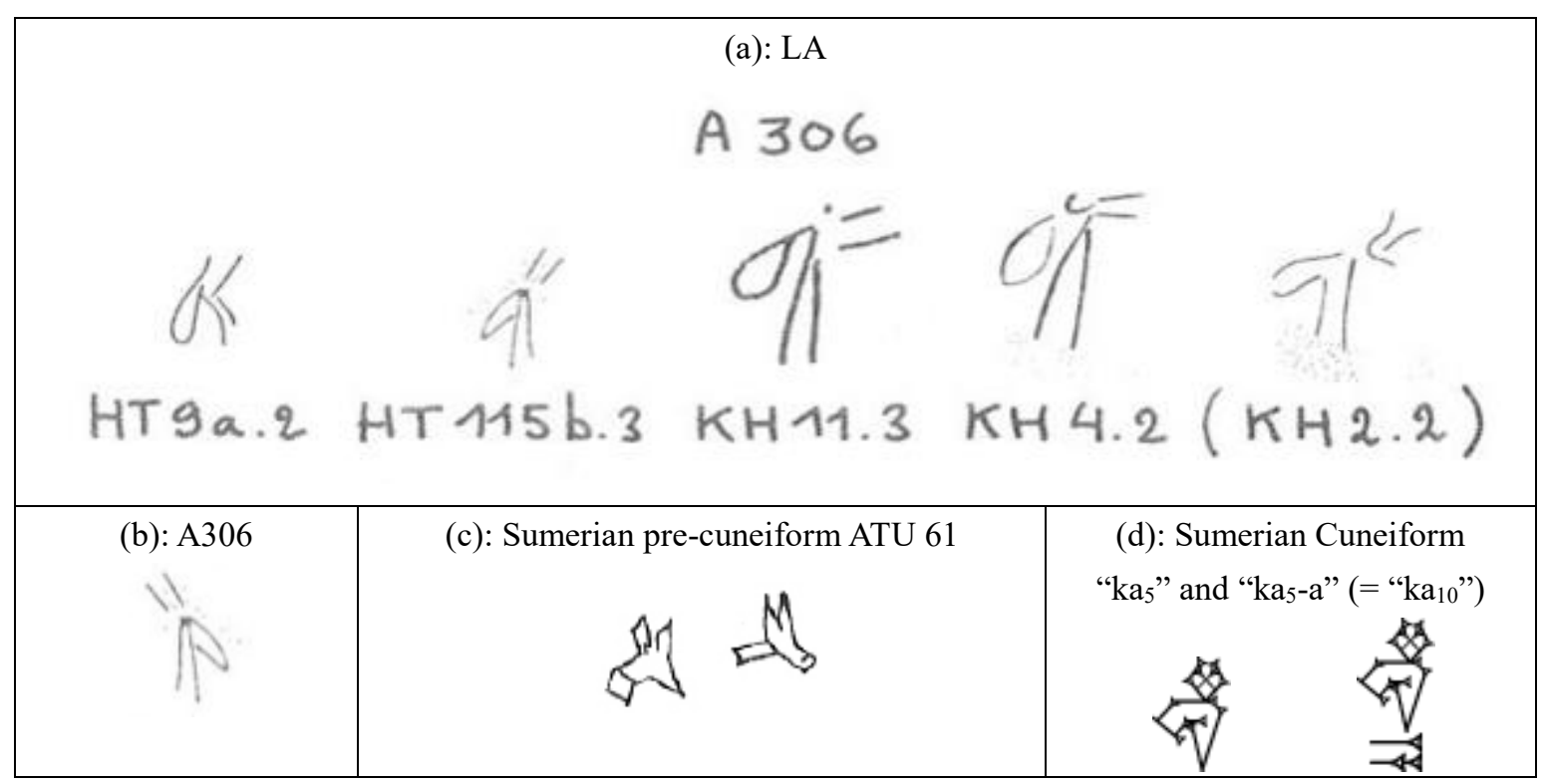

Figure 13. The signs of fox

\subsection{Syllabogram "rə"}

Both a syllabogram (LB33) and a logogram for "saffron" (figure 14a), this sign was sometimes used for the syllables " $\rho \alpha \iota "$ " approximately /roj/) or " $\lambda \alpha \iota$ " (approximately /ləj/) in Greek (LB). It meant flowers in general, and, par excellence, the flower of crocus, which it depicts in particular, due to the great economic and cultural significance of the crocus flower (Dewan, 2015). The word for flower (especially crocus) can be traced in Mesopotamian words as "gi-rin" (figure 14c); "gi 4 -rin" (figure 14d); " "gešs gi-rim" (figure 14e). Their common part alone (figure 14f) was pronounced "rin" or "rim" (only that "rin" or "rim" was originally "flower"; "gi-rin/m" meant the important part of the saffron flower: the pistil, so the sign of figure $14 \mathrm{f}$ alone has also a reading "girin $/ \mathrm{m}$ "). As old Sumerian " $\partial$ " and "a" often turned to "i" and "e" respectively, a well-known phonological trait that we often mention in the present work, and observing that no native Sumerian word started with r-, we conclude that the word for flower was "ron" in old Sumerian (Kenanidis, 2011-2013, pp. 49-51); so this was the sign chosen to use for the syllable "rə" in CP, also in the Cypriot type of Protolinear, as the Linear C (Cypriot Greek) sign RI (from "rə") attests. The same flower sign is also found on the renowned Arkalochori Axe, inscribed in CH (Kenanidis, 2016) in a context that also attests to the phonetic value "rə".

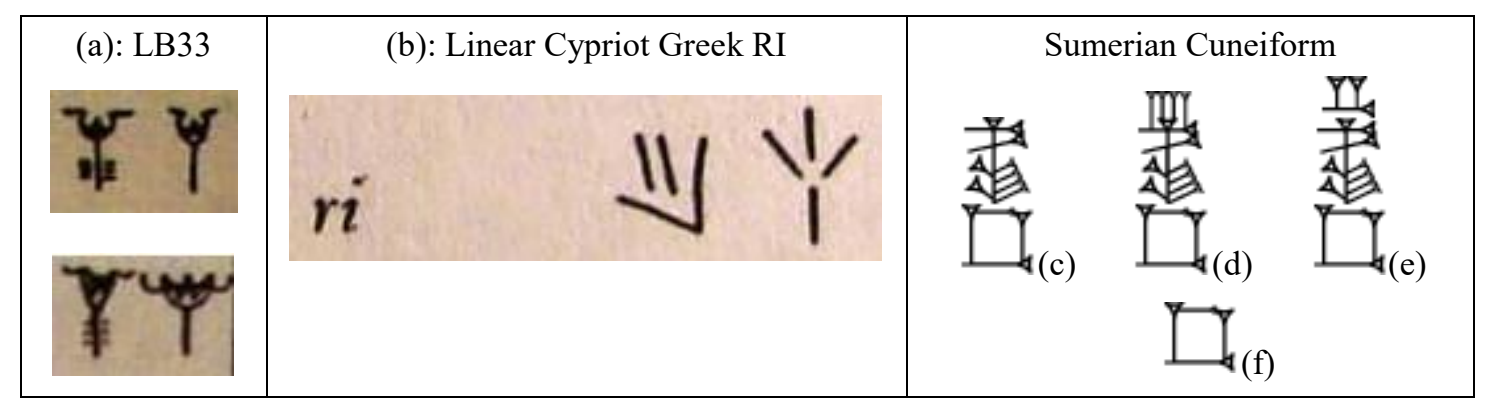

Figure 14. The signs of flower/crocus

\subsection{Syllabogram "sə"}

Prima facie, the rare syllabogram LB63 (figure 15a), of hitherto obscure phonetic value, calls nothing specific to mind nowadays. After our research, it is seen to depict, with manneristic abstraction, an elaborate hairdo. 
Comparing to the renowned Minoan fresco Ladies in Blue (figure 15b), we see the LB63 sign depicting a lock of hair protruding on the right, in front of the face, two hair bundles formed in the middle and a ribbon with a knot

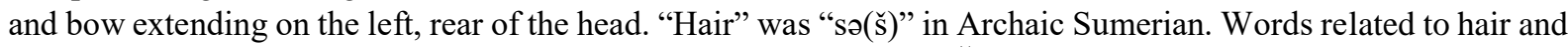
to officials with a special hairdo in Sumerian Cuneiform use the sign ŠID (figure 15d), which resembles the LB63 sing, while other words for "hair" and "hairdo" are found (in PSD) as:

- $\quad$ wr. suhur, "to trim or comb the hair", Akk. šamāţu; qamāmu; kezēru.

- wr. suhur-la 2 , "hairstyle; a functionary; prostitute", Akk. kezertu.

- $\quad$ wr. suhur, "tuft, plume; crown (of a tree)", Akk. qimmatu.

The pictogram "SUHUR" in pre-Cuneiform (figure 15c) is also read as "suh 2 ?". The pictorial origin of SUHUR is not very explicit, but it must have been an imposing hairdo or a crown. Importantly, the sign SUHUR was used as a determinative (i.e., not pronounced, but a classifier) to other words meaning "hair". That word appearing as

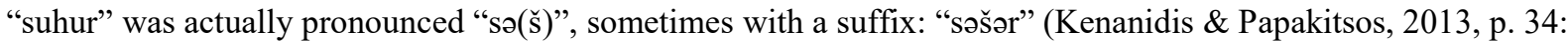
rule 5.0.5, p. 38: rule 5.0.38). So, the CP syllabogram "sə" depicted an elaborate hairdo, to show "human, well kempt, hair".

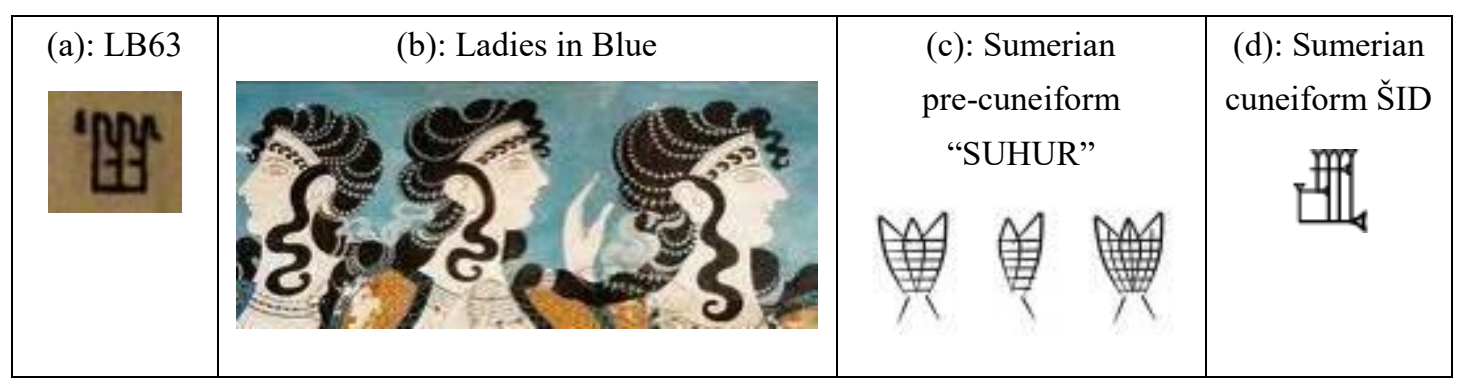

Figure 15. The signs of dressed hair

\subsection{Syllabogram "tə"}

Another syllabogram of this set is LB66 (figure 16a), conventionally " $\mathrm{ta}_{2}$ " in LB where it was actually used for

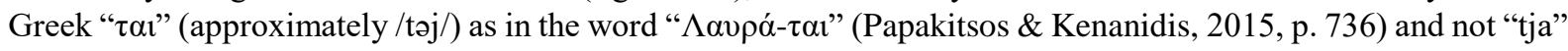
as it is traditionally misinterpreted (since Ventris \& Chadwick, 1953). It conveyed the syllable "to" in CP. The sign depicted a woman's genitals, pronounced "to(l)" in old Sumerian, later "sə(l)", thus the sign is named "SAL" in Cuneiform (figure 16b). It was not a taboo in writing, as the sign SAL and compounds of it were very common in the Cuneiform script (Whittaker, 2001, pp. 17-18).

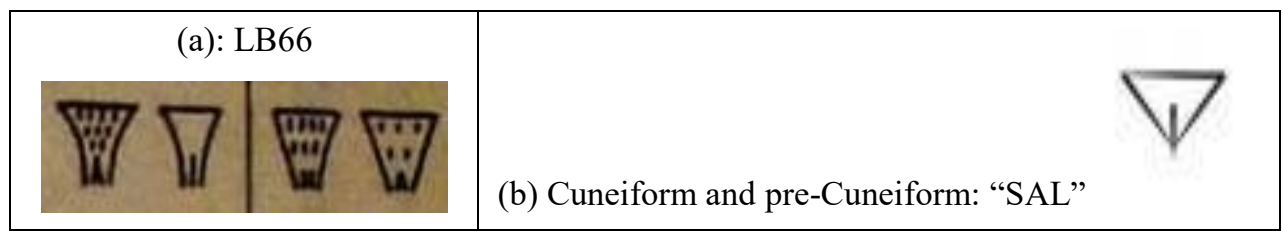

Figure 16. The signs for female genitals

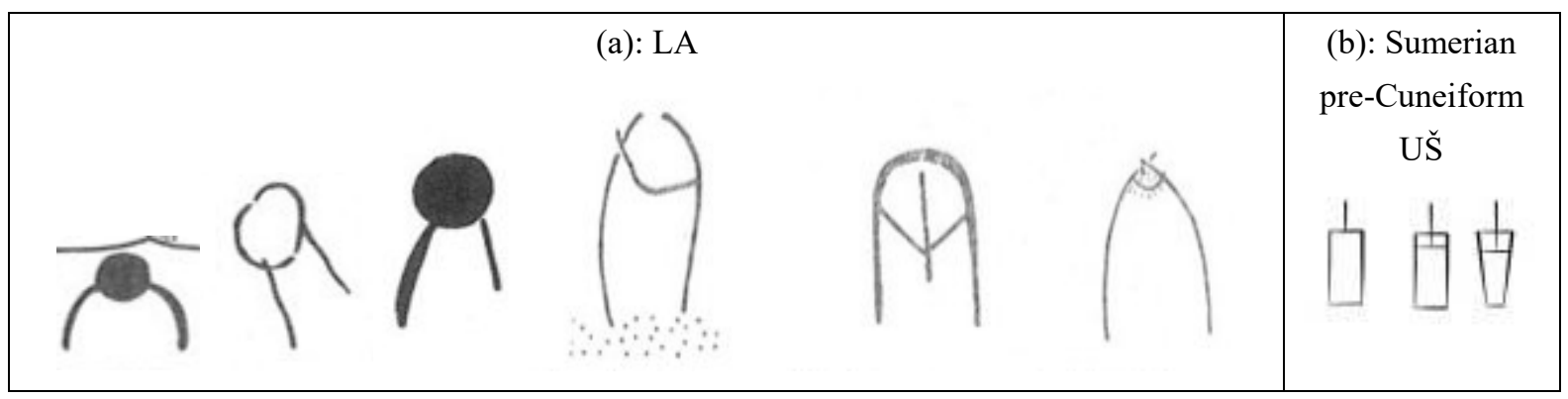

Figure 17. The signs of male organ 


\subsection{Syllabogram "wə"}

The syllabogram"wə", found only in some inscriptions of LA, usually on libation tables (figure 17a), depicts a man's member. The corresponding Sumerian Cuneiform and pre-Cuneiform pictogram was called UŠ (figure 17b), which was the archaic Sumerian name of the male member (Whittaker, 2001, pp. 17-18), pronounced "wə(s)". Thus, the CP sign that depicted a man's member conveyed the syllable "wə".

\subsection{Syllabogram "šs”"}

The syllables of the consonant " $\mathrm{z}$ " in LB were phonetically approximated by the similar sounding š-syllabograms of CP. So, if the CP "šə" were used in LB, it would be named "zə", or "za 2 " presumably; but nobody would expect such a sign to be present in LB, as the LB z-signs are not often in use, and not more frequent are the -ə signs (there was never a syllable "广al" recorded in LB). This sign is found as a syllabogram in LA (figure 18a) and in $\mathrm{CH}$ (figure 18c), but only as a logogram in LB (figure 18b). The logogram is customarily interpreted as "condiment", but it might have meant "perfume" and "incense" as well. It resembles not only a condiment jar with a handle, but also a hand-held censer like those still used in Greece. As a logogram (or "ideogram"), it denoted perfumes, incense and any kind of aromatic substances.

There were, of course, many different aromatic herbs, condiments, and spices, but there was one general and very common word for all such: "šim", itself written ŠIM and used as a determinative too. Determinatives were certain signs when used not to be pronounced but to help the reader classify the word into some category (e.g., plants, birds, places, city names, metallic objects, wooden objects or trees, things made of leather, parts of the body, and so on). Exactly because they expressed broad categories, determinatives were understood as very basic words, and exactly because they were basic, they were most proper to use as CP syllabic signs. Essentially all determinative signs of Cuneiform correspond to things depicted by syllabograms of CP. The PSD gives for "šim":

- $\quad$ wr. šim, "aromatic substance; beer malt", Akk. rīqu (= "aromatic substance").

Remembering again the phonetic correspondence of older ə- to Cuneiform " $\mathrm{i}$ ", the original Sumerian word for perfumes, aromatic herbs and substances was "šə(m)". The CP sign for "ši" was different, found in LB and depicting a net according to Kenanidis (2011-2013). So this was the CP syllabogram for "šs".

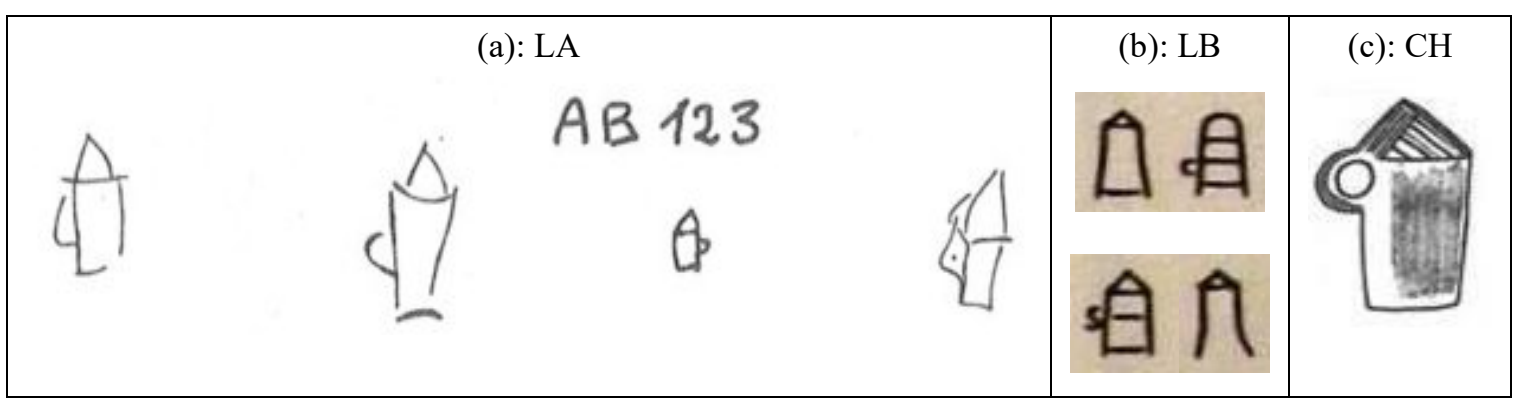

Figure 18. The signs of perfume

\section{Discussion \& Conclusion}

In order to present the entire set of a-vowel syllabograms of $\mathrm{CP}$, we had to present some signs used in $\mathrm{LB}$ for the Achaean Greek [əj], [ə] apparently being the allophone of "a" before /j/ except in "-ajV-" (V = vowel), but also we had to discover more signs of syllables not used in LB, because such syllables, or some of their consonants, were strange to Achaean Greek phonology: such consonants were the Sumerian "b" (see subsection 3.2), "z" (/9/, see subsection 3.4), "ĝ" (//y/, in subsection 3.5) and "h" $(/ \mathrm{x} /$, partially used in Greek for $/ \mathrm{h} /$, see subsection 3.6). The evidence for non-Greek consonants in LB has been already suspected by Melena $(2000$, p. $26: / \mathrm{mb} / \mathrm{V})$. In the present work we have shown the pictorial origin and phonetic use of LB *18 (figure 3), *63 (figure 15), *82 (figure 12), *86 (figure 10) and *89 (figure 11), which belong to "the un-transliterated syllabograms". Generally, LB signs with "ə" were rare or not very common in use, but also other CP signs of syllables unusual in Greek language were totally absent or very rare in LB; such are "the un-transliterated syllabograms" of LB numbered as *19, *22, *34, $* 35, * 47, * 49, * 56, * 64, * 65, * 79, * 83$, whose pictorial origin and phonetic value has also been revealed by our research that will be presented in a future publication, which, we hope, will facilitate the reading of many hitherto obscure words and inscriptions of LB. In conclusion, it has been demonstrated in this work how the phonetic value of each presented syllabogram corresponds to the Sumerian name (in a conservative dialect) of the object depicted 
by the syllabogram, thus shedding light on the linguistic ancestry of Minoan scripts, the practice followed for their creation and several unknown phonetic values of hitherto un-transliterable syllabograms.

\section{Acknowledgments}

The authors would like to express their thankfulness to the French School of Athens. Its digital archives greatly facilitated the research presented here. Also, this work would be quite inferior if there were not the Cuneiform Digital Library Initiative (CDLI). Even the main dictionary for Sumerian today (the PSD) is available at the CDLI's tools webpage.

\section{References}

Davis, B. (2011). Cypro-Minoan in Philistia? KUBABA, 2, 40-74.

Dewan, R. (2015). Bronze Age Flower Power: The Minoan Use and Social Significance of Saffron and Crocus Flowers. Chronika, $V$, 42-55.

Dickinson, O. (1994). The Aegean Bronze Age. Cambridge and New York: Cambridge University Press.

Driver, G. (1976). Semitic Writing from Pictograph to Alphabet. Revised edition by S.A. Hopkins of the original: 1948, Oxford University Press.

Falkenstein, A. (1936). Archaische Texte aus Uruk (ATU). Ausgrabungen der Deutschen Forschungsgemeinschaft in Uruk - Warka (volume II). Berlin.

Haarmann, H. (2008). The Danube Script and Other Ancient Writing Systems: A Typology of Distinctive Features. Journal of Archaeomythology, 4(1), 12-46.

Kenanidis, I. (1992). EteokreetesMegaleetores. Athens: National Library of Greece (in Greek).

Kenanidis, I. (2011-2013). Historical and Linguistic Studies: cwepeker.doc. Kavala, Greece: E.P. Lazidou (in Greek).

Kenanidis, I. K. (2016). A 17th c. BC Minoan Votive Double Axe (Labrys). The Arkalochori Axe and its siblings. Anistoriton Journal, In Situ, 15(1), 1-20.

Kenanidis, I. K., \& Papakitsos, E. C. (2015a). The Eteocretan Inscription from Psychro (Crete) is Genuine. Anistoriton Journal, ViewPoints 14(2), 1-7.

Kenanidis, I. K., \& Papakitsos, E. C. (2015b). A Comparative Linguistic Study about the Sumerian Influence on the Creation of the Aegean Scripts. Scholars Journal of Arts, Humanities and Social Sciences, 3(1E), 332346.

Kenanidis, I. K., \& Papakitsos, E. C. (2017). Linguistic and Cultural Aspects of Disyllabic Signs in the Cretan Protolinear Script. Scholars Bulletin, 3(10), 489-496. https://doi.org/10.21276/sb.2017.3.10.9

Kenanidis, I., \& Papakitsos, E.C. (2013). Yet another suggestion about the origins of the Sumerian language. International Journal of Linguistics, 5(5), 30-44. https://doi.org/10.5296/ijl.v5i5.4107

Kramer, S. N. (1963). The Sumerians. Their History, Culture, and Character. Chicago: The University of Chicago.

Melena, J. L. (2000). On The Structure of the Mycenaean Linear B Syllabary: I. The Untransliterated Syllabograms. In 11th International Colloquium on Mycenaean Studies, Austin, Texas, 7th - 12th May 2000.

Owens, G. A. (1990). Three Re-Discovered Linear A Inscriptions from Knossos. Minos, 25, 367-372.

Owens, G. A. (1996). The Common Origin of Cretan Hieroglyphs and Linear A. Kadmos, 35(2), 105-110.

Papakitsos, E. C., \& Kenanidis, I. K. (2015). Additional Palaeographic Evidence for the Relationship of the Aegean Scripts to the Sumerian Pictography. Scholars Journal of Arts, Humanities and Social Sciences, 3(3C), 734737.

Papakitsos, E. C., \& Kenanidis, I. K. (2016). Cretan Hieroglyphics: The Ornamental and Ritual Version of the Cretan Protolinear Script. Anistoriton Journal, Essays, 15(2), 1-12.

Schoep, I. (1999). The Origins of Writing and Administration on Crete. Oxford Journal of Archaeology, 18(3), 265-276.

Soden, von W. (1958-1981). Akkadisches Handwörterbuch (AHW). Wiesbaden.

Ventris, M. G. F., \& Chadwick, J. (1953). Documents in Mycenaean Greek. Cambridge: Cambridge University Press.

Whittaker, G. (2001). The Dawn of Writing and Phoneticism. In D. Borchers, F. Kammerzell, \& S. Weninger (Eds.), 
Hieroglyphen, Alphabete, Schriftreformen (LingAeg - Stud. mon. 3, pp. 11-50). Göttingen.

Willetts, R. F. (1977). The Civilization of Ancient Crete.Oakland, CA: University of California Press.

Woudhuizen, F. C. (2005). The Language(s) of Linear A: An Updated Review Article. DO-SO-MO: Fascicula Mycenologica Polona, 6, 95-121.

\section{Notes}

Note 1. http://psd.museum.upenn.edu/epsd/index.html

Note 2. quoting from https://en.wikipedia.org/wiki/Vowel\#Roundedness retrieved 2017, February 20. Although it is only a "wiki", all statements there about vowel roundedness express the common knowledge of all modern linguists based on observation of the world's languages; that is why those particular statements are not referred to any particular publication.

Note 3. For readers unfamiliar to the IPA, please note that /y/ is a vowel, namely the close front rounded vowel, and nothing like English " $\mathrm{y}$ ".

Note 4. https://en.wikipedia.org/wiki/Manchu_language\#Vowel_harmony; retrieved 2017, February 17.

Note 5. Lyrics and music available at:

http://eksd.org.tr/bestecilerimiz/sadeddin_kaynak/buselik_saclarima_ak_dustu_sana_ad_bulamadim.pdf

Note 6. e.g., see a Hellenistic poem about a "gallos":

http://www.perseus.tufts.edu/hopper/text?doc=Anth.+Gr.+6.217\&fromdoc=Perseus\%3Atext\%3A2008.01.0472

Note 7. Available at: https://cdli.ucla.edu/tools/SignLists/protocuneiform/archsigns.html

Note 8. http://www.palaeolexicon.com/Word/Show/18460

\section{Copyrights}

Copyright for this article is retained by the author(s), with first publication rights granted to the journal.

This is an open-access article distributed under the terms and conditions of the Creative Commons Attribution license (http://creativecommons.org/licenses/by/4.0/). 